\title{
Partial and total rejuvenation pruning of sour cherry trees
}

\author{
Csihon, Á., Dremák, P. \& Gonda, I. \\ University of Debrecen, Faculty of the Agricultural and Food Sciences and Environmental \\ Management, Institute of Horticulture \\ 138. Böszörményi str., Debrecen, H-4032, Hungary
}

\begin{abstract}
Summary: Sour cherry can be considered as a special fruit species regarding the growing characteristics, as most of the cultivars are characterized by strong balding. With the aging of the tree the inactive (passive) parts of the canopy are increasing steadily, so the productive cropping surface and the yielding capacity decrease significantly. In our experiments partial rejuvenation pruning was carried out in a 12 years old orchard, and total rejuvenation pruning was performed in a 21 years old plantation to regenerate the cropping surface of the trees. Thanks to the latter one the canopy of the sour cherry trees were regenerated during only two years. The yields of the rejuvenated trees in cv. 'Debreceni bötermö' exceeded the yields of the control trees, as in the case of the cvs. 'Érdi bötermő' and 'Újfehértói fürtös' approached it. At the same time the total rejuvenation pruning has a positive effect on the fruit size.
\end{abstract}

Keywords: sour cherry cultivars, balding, partial rejuvenation pruning, total rejuvenation pruning

\section{Inroduction}

Sour cherry is a special fruit species concerning its growing characteristics (Szabó et al. (2006). The yield is produced on the one-year-old shoots and on the fruiting bouquets. New shoots on the twigs usually form only from the terminal buds, as after yielding the twigs became inactive (Gonda, 2008). Accordingly due to the growing characteristics balding seems inevitable, only its intensity can be reduced. Therefore after a time the productive cropping surface of the trees starts to decrease, what results in the loss of the yielding capacity (Gonda, 2010).

Pruning of cherry cultivars is also dependent on timing of pruning (Gonda, 2006) and has great effect on growing characteristics and fruit quality (Gonda \& Király, 2005; Gonda et al., 2007) as well as it can greatly reduce brown rot blossom blight and fruit rot (Holb, 2006, 2008).

Among the yielding capacity of the various years old parts of the canopies of the sour cherry cultivars, that is the scale of the balding processes there are significant differences. Gonda \& Such (2008) examined five sour cherry cultivars ('Újfehértói fürtös', 'Érdi bőtermő', 'Debreceni bőtermő', 'Kántorjánosi 3', 'Érdi jubileum'), and determined the yielding capacity of the various years old parts of the canopies. In their work they also stated that even in neglected, unpruned orchards there is a possibility for the rejuvenation of trees from stumps after pruning the older parts. However, in certain cultivars the regeneration of older parts is uncertain.

\section{Partial rejuvenation pruning}

When partial rejuvenation is carried out, on the one hand the aim is to perform a general thinning in the canopy at the end of the winter, but the main goal is to cut back 1-3 main branches of the central axis to promote their regeneration. The length of the stumps measured from the axis must be between $100-120 \mathrm{~cm}$ in the lower region of the tree, and must be between $30-50 \mathrm{~cm}$ in the higher zones. These distances also depend on the size of the canopy and the length of the bald branches. In optimal case on the old branches which were cut back there are younger, four- three-years-old parts, which also must be cut back to facilitate the germination of the hidden buds (Gonda, 2008, 2010).

\section{Total rejuvenation pruning}

At the age of 10-12 years sour cherry trees start to bald significantly, which can be observed mainly in the inner branches of the canopy. Ratio of the inactive parts of the tree can reach even $50 \%$, as the active fruit bearing parts are located in the periphery of the canopy. Maintaining of the bald zones requires huge amount of energy, which is covered from the supply of the active parts. Parallel with this process the fruit size and naturally the nutrient value decreases in the case of the most cultivars partially regardless from the vintage affect. Balding occurs not only in the 5 years old, or older branches, but in the 2-4 years old parts also. Taking into consideration these phenomenon the total rejuvenation pruning of the older sour cherry trees, that is the stronger cutting back of the main branches and the central axis can result in a more efficient and faster regeneration.

In our experiments partial and total rejuvenation pruning were carried out in old sour cherry trees in order to determine the regeneration ability of the stumps with different age and the available yields of the regenerated trees. 


\section{Materials and methods}

\section{Parameters of the experimental site}

Parameters of experimental design. Briefly, the location is University of Debrecen, Pallag Experimental Station of Horticulture. Year of planting is 1994. Trees were grafted on rootstock: (Prunus mahaleb) Assessed cultivars were 'Újfehértói fürtös', 'Érdi bőtermő', 'Debreceni bőtermő', 'Kántorjánosi 3'. Planting design was $6 \mathrm{~m}$ x $3 \mathrm{~m}$. Canopy type was spindle with diffused branches.

\section{Partial rejuvenation pruning}

The number of shoots emerging from the buds of the stumps was quantified in the 12 years old trees in the case of three cultivars (cvs. 'Debreceni bőtermő', 'Kántorjánosi 3', 'Érdi bőtermő'). The observed trees were unpruned in the previous three years, thus the density of the canopy was high. The 2-5 years old and 10-20 cm long stumps were created in spring of 2005, when the common pruning was carried out. At the end of the vegetation period, at leaf fall time, the shoot formation from the hidden buds of the stumps was measured.

\section{Total rejuvenation pruning}

In an irrigated, 21 years old orchard with good condition the trees were rejuvenated with strong pruning in the case of three cultivars ('Újfehértói fürtös', 'Érdi bötermő', 'Debreceni bötermő') in 2013. Before the treatment the trees could be described with significant balding (Photo 1), so the yields varied in most of the years between $15-25 \mathrm{~kg} /$ tree, that is $8-14$ tons/ha.

The inactive main branches of the central axis balded in different scale depending on the cultivars were cut back with Stihl saw, in a way that the length of the stumps decreased from the bottom to the top. After pruning the length of the stumps varied between $120-150 \mathrm{~cm}$ in the lower zone, $50-80$ $\mathrm{cm}$ in the middle of the canopy and $30-50 \mathrm{~cm}$ in the top of the tree. During cutting back the branches the existence or the location of the four- three- two-year-old parts less or not at all influenced the degree of the pruning, as the main aim of the pruning was not to leave these parts in the canopy. The work rather focused on to ensure the optimal conical canopy shape with the appropriate stump length.

Two years after the treatment the specific flower density (flower number/branch cross sectional area), the yields and the fruit size were determined in the regenerated trees.

\section{Results and discussion}

\section{Partial rejuvenation pruning}

Figure 1 shows the shoot number of the crown parts of different ages in the partially rejuvenated trees in 2005 . It can be seen that the germination of the hidden buds, that is the regenerative shoot formation was the highest in the three and four years old stumps. Regeneration in the two and five years old parts was lower, but the cv. 'Kántorjánosi 3' showed the highest values in the five year old stumps. Regeneration ability of the cv. 'Érdi bötermö' outstands, but the five years old parts have lower shoot formation.

Based on this the rejuvenation of the bald branches of sour cherry can be successful, if there are 3-6 years old branches in the adequate (inner) parts of the canopy. However the partial rejuvenation pruning did not help the germination of the hidden buds of the older, thicker, inner branches, as they remained still inactive.

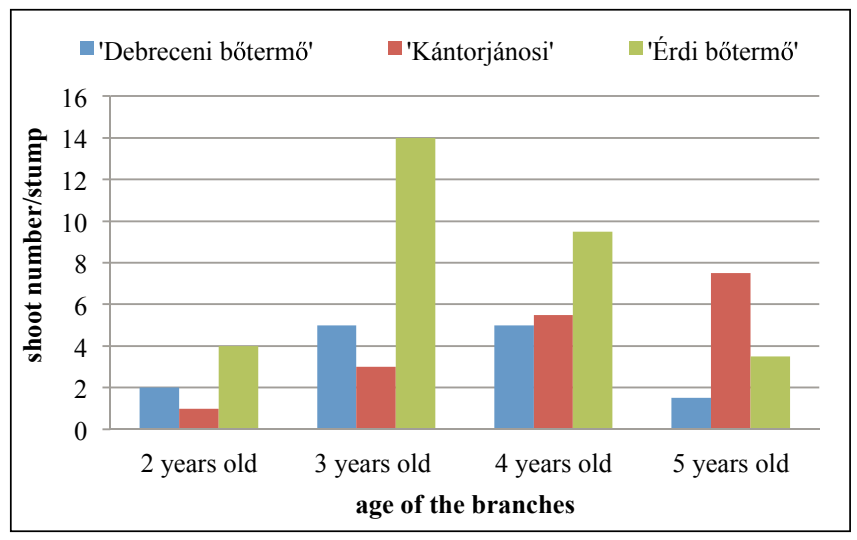

Figure 1. Effect of the partial rejuvenation on the regeneration of the crown parts of different ages (Debrecen - Pallag, 2005).

\section{Total rejuvenation pruning}

After the treatment the trees showed a forbidding vision (Photo 2). With the progression of the vegetation period the trees became more green by the germination of the hidden buds (Photo 3). In the winter of 2014 huge amount of shoots appeared in the trees, which contained also flower buds (Photo 4). Two years after the pruning (in 2015) trees are regenerated practically fully, lots of shoots and twigs were formed (Photo 5). Significant number of flower was measured on these parts, which is presented in Figure 2. The data shows that the cv. 'Érdi bötermö' reached the highest specific flower number (flower number/stump cross sectional area), as the cvs. 'Debreceni bőtermő' and 'Újfehértói fürtös' can be described with lower values.

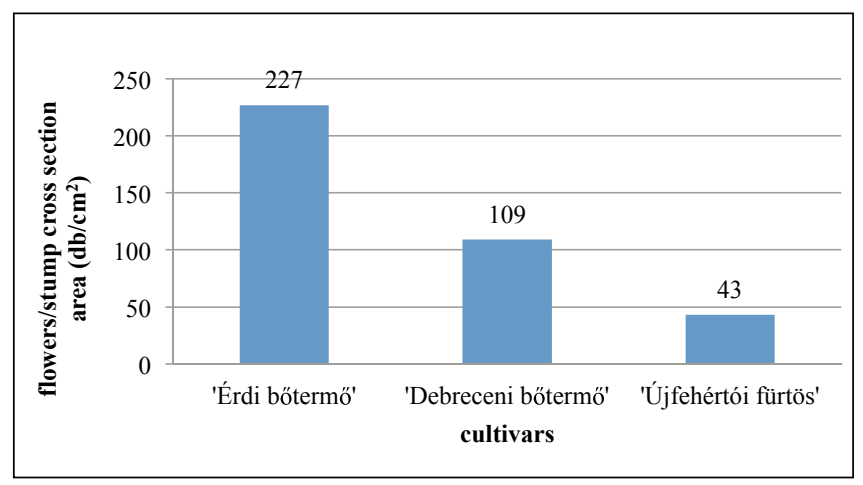

Figure 2. Specific flower number of the totally rejuvenated sour cherry trees two years after the pruning (Debrecen - Pallag, 2015). 


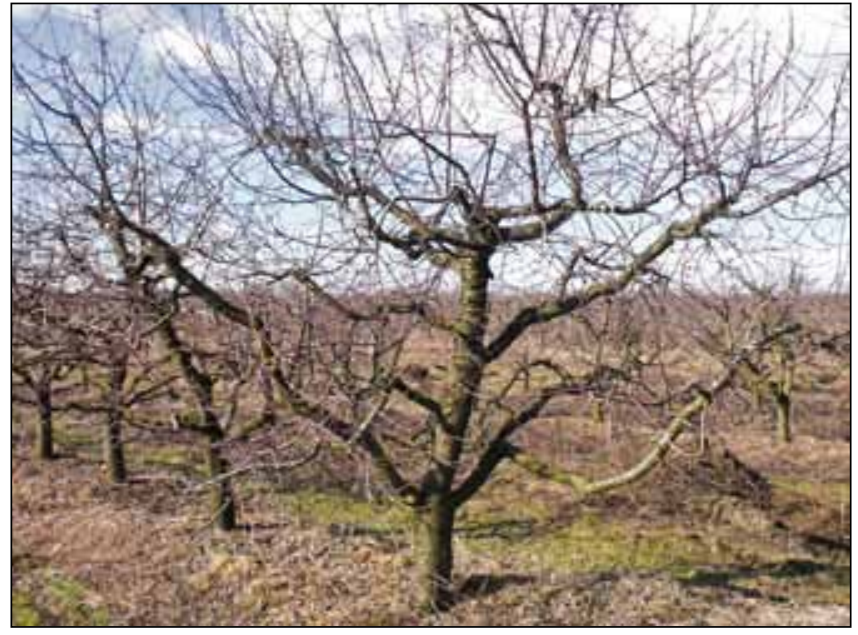

Photo 1: Strongly balded sour cherry tree at age of 21

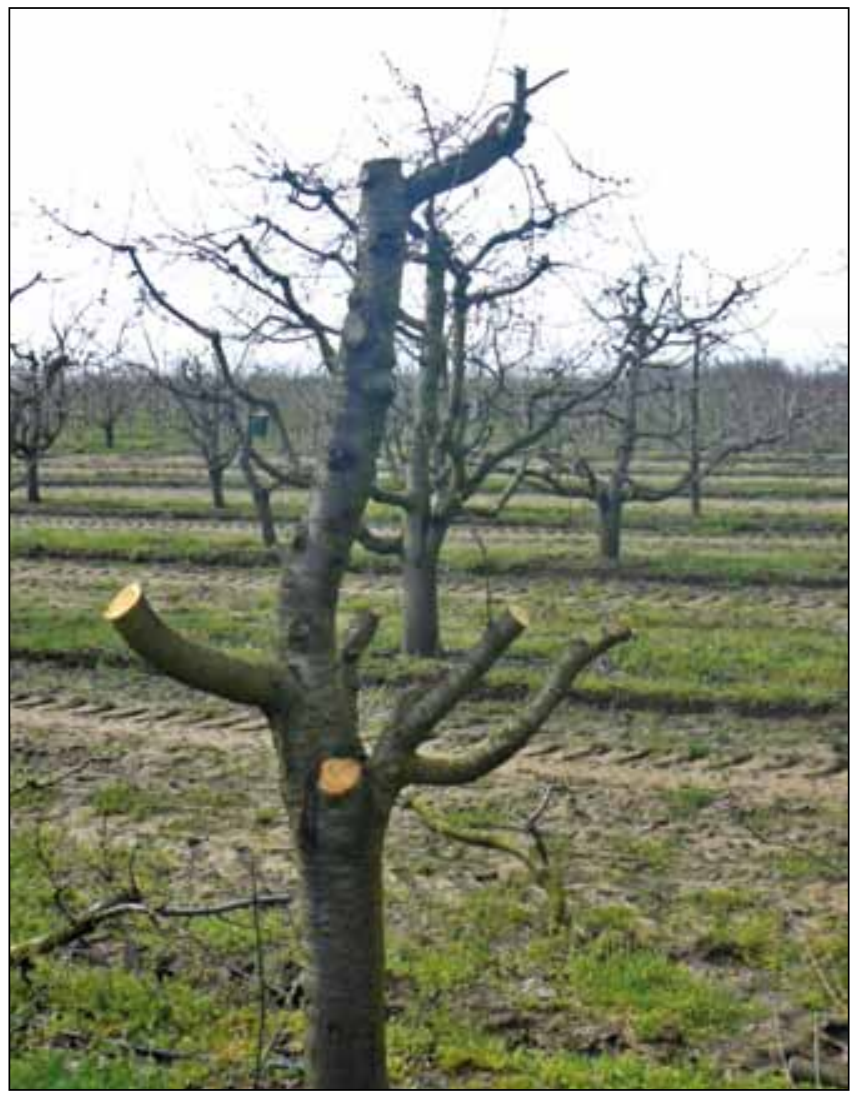

Photo 2: Total rejuvenation pruning on sour cherry tree

The yield of the control and the rejuvenated trees in 2015 is shown in Figure 3. It can be seen, that in cv. 'Debreceni bötermö' the harvested yield is slightly higher in the regenerated trees with similar stump length compared to the control. In the case of the cv. 'Érdi bötermö' the yield of the treated trees was lower with $40 \%$, as the cv. 'Újfehértói fürtös' produced $60 \%$ lower fruit amount two years after the total rejuvenation pruning. Obviously the differences among the cultivars can be explained with their ramification ability and the scale of the balding processes. In cv. 'Debreceni bötermö' much more four- three- two-year-old parts left on the main branches after the pruning compared to the cv. 'Érdi bőtermő', as in the trees of the 'Újfehértói fürtös'

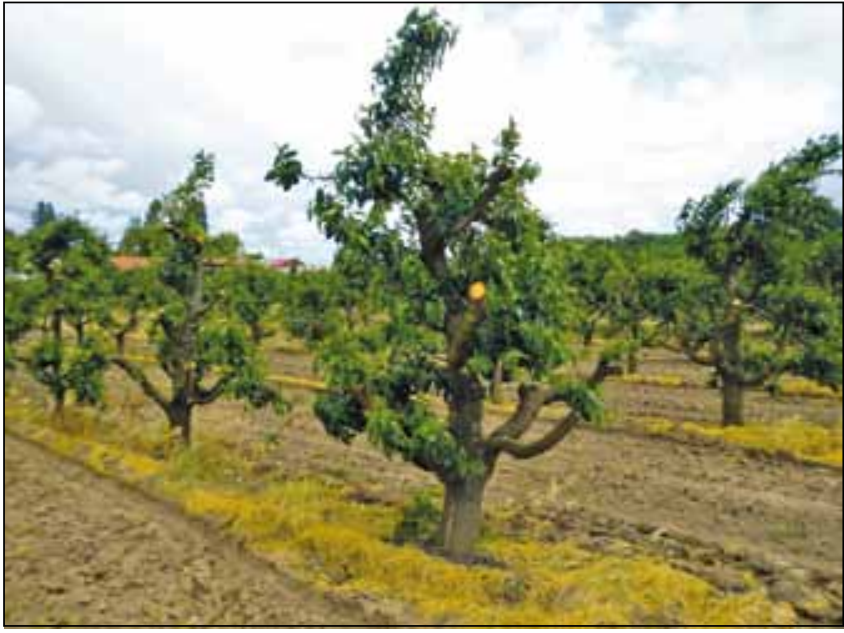

Photo 3: Huge amount of shoots appear after the treatment

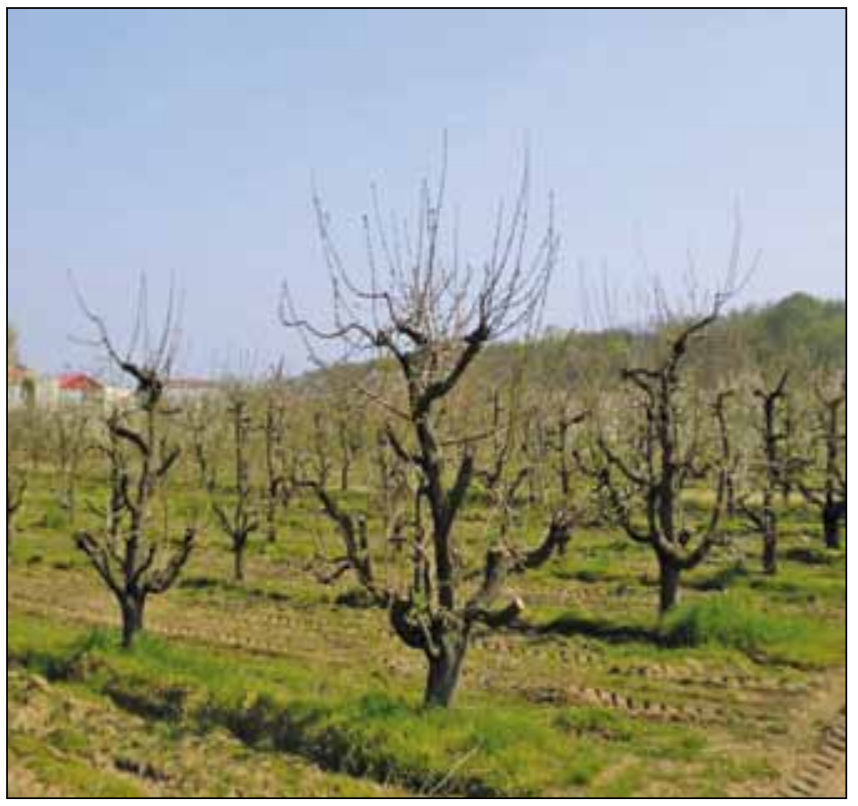

Photo 4: One year after the pruning there are lots of shoot in the canopy

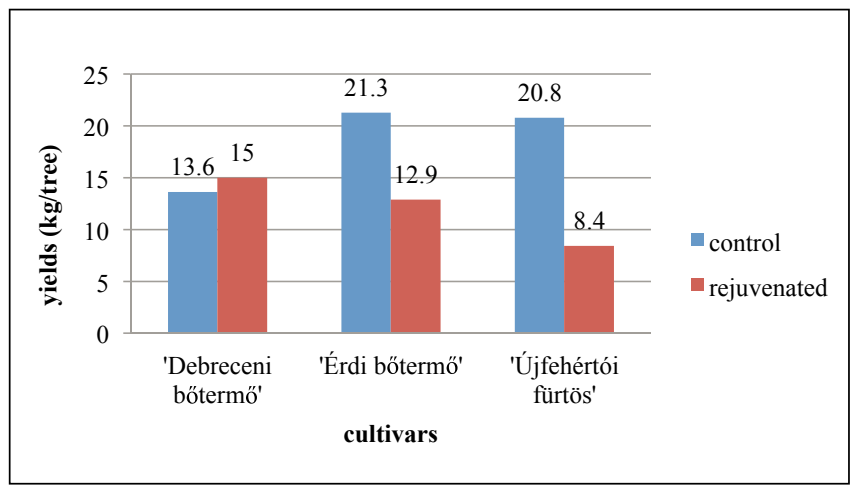

Figure 3. Yields of the control and the rejuvenated trees two years after the pruning (Debrecen - Pallag, 2015).

practically only bald stumps left after sawing. Accordingly the last two cultivars did not have the chance to develop the complete cropping surface during only two years. Based on our expectations this differences among the cultivars will be levelled off in the next year. 
Regarding the fruit size the total rejuvenation pruning has an unambiguous positive effect (Figure 4). The treated trees in cvs. 'Érdi bőtermő' and 'Debreceni bőtermő' produced $7-8 \%$ larger fruits compared to the control, as the 'Újfehértói fürtös' reached 5\% larger fruit in the rejuvenated trees. Obviously this is due to the stronger shoot growth.

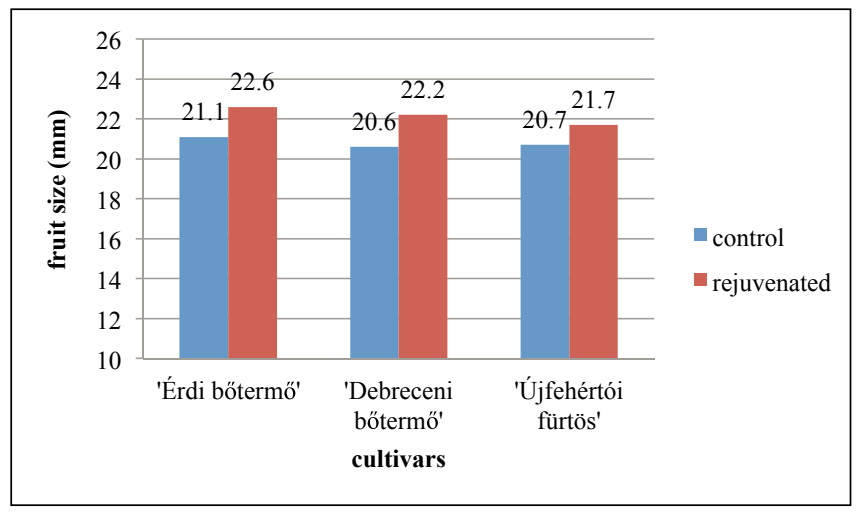

Figure 4. Fruit size of the control and rejuvenated sour cherry trees (Debrecen - Pallag, 2015).

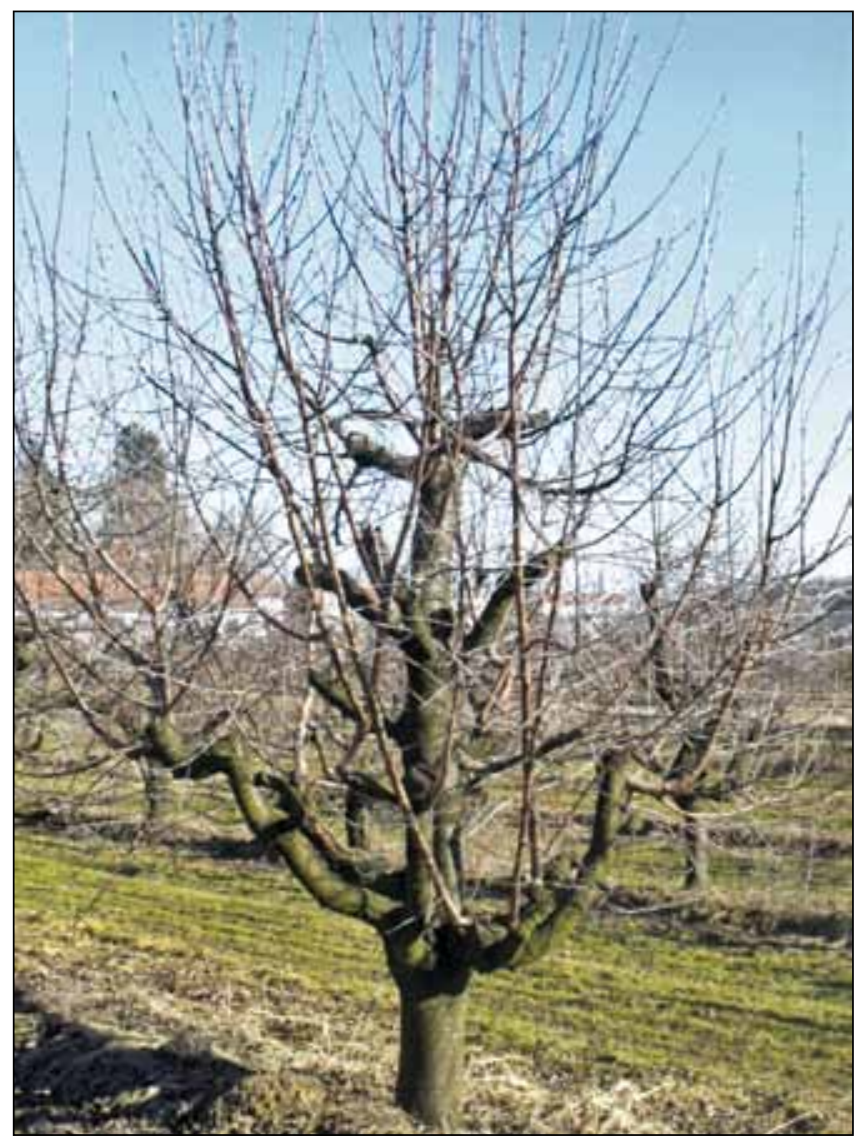

Photo 5: Two years after the treatment the trees are regenerated totally

\section{Conclusions and recommendations}

Based on the examinations the followings can be stated:

- The total rejuvenation pruning can result in more certain, more efficient and faster regeneration compared to the partial rejuvenation pruning, if the condition of the orchard is adequate.

- According to our expectations the total rejuvenation pruning of 20 years old, irrigated sour cherry trees with good condition can prolong the productive period at least with 10 years.

- The better utilization of the sunlight, that is the better illumination of every part of the canopy (the total utilization of the incoming sunlight) makes possible the better regeneration.

- The stimulating effect of the germination of the unharmed root system can prevail more powerfully in the case of adequate water supply.

- When total rejuvenation pruning is carried out only the year of the treatment means whole yield loss. One year after the total rejuvenation pruning $1 / 4$ or $1 / 3$ yield can be harvested, as one more year later even $100 \%$ yield can be reached depending on the cultivars (Photo 6).

- The fruit size increases unambiguously (5-8\% in our experiments) in the rejuvenated trees compared to the control trees.

- The efficiency of the total rejuvenation pruning can be increased if germination forcing interventions (e.g. nicking above the bud) are carried out in the inner canopy parts 1-2 years before the radical pruning. This also contributes to the minimization of the yield loss after the rejuvenation pruning, as there are fruit bearing parts on the tree when the sawing is performed.

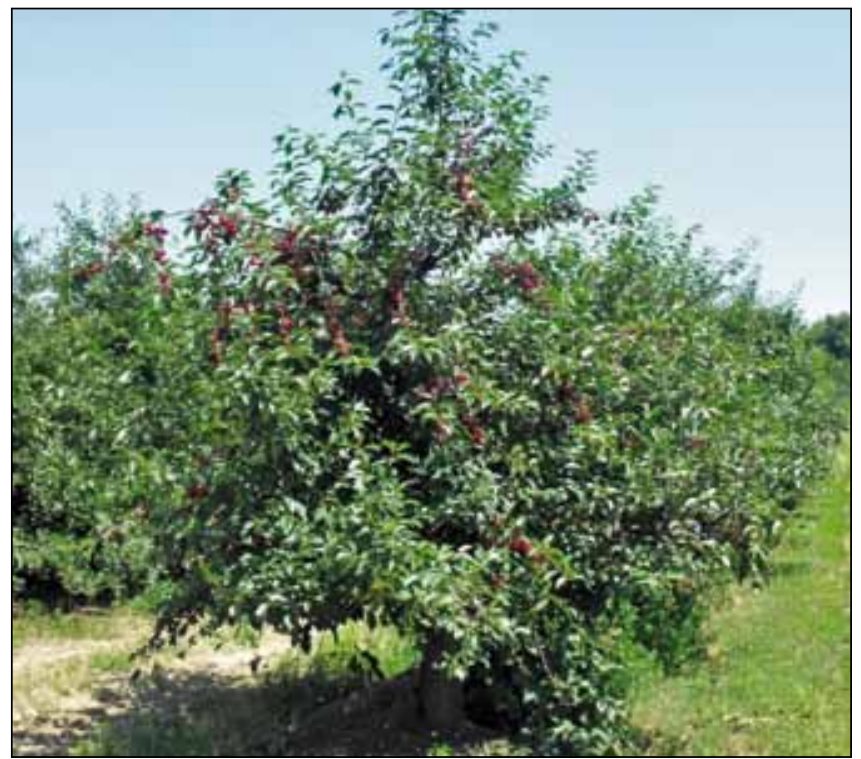

Photo 6: Regenerated sour cherry trees with yield in summer of 2015

\section{References}

Gonda I. (2006): The size of the canopy of sour cherry trees depends on the time of pruning. International Journal of Horticultural Science, 12 (3): 49-52. 
Gonda I. (2008): A meggy művelési rendszere, koronaformái és a fák metszése [In: Nyéki et al. (szerk.): Meggyültetvények létesítése és termesztéstechnológiája.] Debreceni Egyetem AMTC KFI. 29-33. p.

Gonda, I. (2010): Csonthéjas gyümölcsfák metszése. DE AMTC Kutatási és Fejlesztési Intézet, Gonda István Betéti társaság.

Gonda, I., Király K. (2005): A nyári metszés hatása a meggyfajták növekedésére és gyümölcsminőségére. Kertgazdaság, 37 (1): 45-52.

Gonda, I., Király, K., Holb, I.J. (2007): Examination of growth of cherry cultivars adapted to intensive production. Acta Horticulturae: Technical Communications of ISHS, 732: 429-434.
Gonda, I., Such, Z. (2008): Yielding capacity and regeneration of different ages fruit-bearing shoots in sour cherry. International Journal of Horticultural Science, 14 (1-2): 55-57.

Holb, I.J. (2006): Incidence of brown rot blossom blight caused by in organic sour cherry production in Hungary. International Journal of Horticultural Science, 12 (2): 133-136.

Holb, I.J. (2008): Brown rot blossom blight of pome and stone fruits: symptom, disease cycle, host resistance, and biological control. International Journal of Horticultural Science, 14 (3): 15-21.

Szabó Z., Szabó T., Gonda I., Soltész M, Thurzó S., Nyéki J. (2006): The current situation of sour cherry production and possibilites for development. Hungarian Agricultural Research, 15 (3): 4-12. 